DOI: $10.19195 / 2353-8546.4 .8$

\author{
BEATA SIWEK*
}

Katolicki Uniwersytet Lubelski Jana Pawła II (Lublin, Polska)

\title{
Dramat i teatr białoruski w poszukiwaniu tożsamości kulturowej
}

Belarusian drama and theatre in search of a cultural identity. In the present article an attempt to present the most important issues concerning identity discourse within Belarusian cultural and literary space has been made. The author of the article is particularly interested in Belarusian dramaturgic texts, which undoubtedly played an important role in forming cultural peculiarity of the Belarusian nation and, simultaneously, which account for an important voice in the discussion on Belarusians' national autonomy. Belarusian drama, so varied in its forms and language material, realising so many different themes and ideas and tackling such a wide range of problems, is not only helpful in searching for answers to a question where the roots of the Belarusian nation are, but it allows us to observe numerous conditionings (not only cultural, but political and religious as well) of the process of Belarusians' identity formation.

Keywords: drama, theatre, cultural identity, Russification, multiculturalism

Белорусские драматургия и театр в поисках культурной идентичности. Современные белорусские драматургия и театр формируются под влиянием исключительно непростой культурной ситуации. Гетерогенность белорусской культуры, слабая позиция белорусского языка, сложные принципы финансирования и управления культурой, а также тяжелая политическая реальность не создают благоприятных условий для формирования национальных ценностей, усложняя тем самым процесс национальной самоидентификации белорусов. Значительные изменения, произошедшие в пространстве белорусского театра и драматической литературы после 1991 года (возникновение театров-студий, создание Республиканского театра белорусской драматургии «Свободная сцена», обращение к западноевропейской и белорусской экспериментальной драматургии, продвижение белорусской драматической литературы предыдущих эпох),

* Adres do korespondencji: Katedra Literatury Ukraińskiej i Białoruskiej IFS KUL, Al. Racławickie 14, 20-950 Lublin. E-mail: beata.siwek@kul.lublin.pl. 
к сожалению, оказались краткосрочными. Новая, постимперская действительность Белоруссии оказалась слишком сложной, полной идентичностных дилемм и не способствующей развитию оригинальных белорусских ценностей. В настоящее время тексты белорусскоязычных драматургов (Алесь Петрашкевич, Сергей Ковалев, Алексей Дударев, Лявон Вашко, Игорь Сидарук) все реже ставятся на белорусской сцене, на которой доминирует молодое поколение русскоязычных литераторов (Павел Пряжко, Николай Халезин, Андрей Курейчик, Сергей Гиргель, Анатолий Шурпин, Константин Стешик, Андрей Карелин, Николай Рудковский), которые добиваются успехов также за пределами Белоруссии, прежде всего в России и Польше.

Ключевые слова: драматургия, театр, культурная идентичность, русификация, поликультурность

„Mamy białoruską przestrzeń kulturalną, której dynamika jest wyznaczana nie przez frontalne natarcia i nowe "ideologie ogólnospołeczne«, lecz raczej przez indywidualne i grupowe projekty kulturalne. Przestrzeń kulturalna przestaje być jednorodna, homogeniczna, obowiązkowa i po sowiecku nudna. $\mathrm{W}$ tej przestrzeni mamy dzisiaj co najmniej pięć postaci kultury białoruskiej: sowiecko-białoruską, awangardową (w szerokim sensie), wileńską, białostocką i emigracyjną, które przenikają się nawzajem i tworzą mozaikę białoruskości, widoczną "nawet dla nie-specjalistów «”-1_pisał białoruski filozof Ihar Babkou w eseju pt. O Odrodzeniи (Аб Адраджэнні). W kontekście podjętego przez nas tematu słowa te wydają się szczególnie znaczące, gdyż odsyłają do zagadnień niezwykle złożonych, aczkolwiek kluczowych dla zrozumienia fenomenu współczesnej kultury białoruskiej.

O owej różnorodności i heterogeniczności kulturowej Białorusi świadczy bez wątpienia współczesny teatr białoruski, a także powstająca w ostatnich latach literatura dramatyczna. Poszukując przyczyn takiego stanu rzeczy, należy cofnąć się do okresu, który w sposób zdecydowany zmienił oblicze teatralne i literackie Białorusi, a więc do przełomu lat osiemdziesiątych i dziewięćdziesiątych minionego stulecia, zwanego powszechnie okresem transformacji ustrojowej, a w sferze kultury — okresem białoruskiego odrodzenia (jakże często porównywanym z okresem „naszoniwskim”). Przemiany polityczne i społeczne, jakie zostały zapoczątkowane $\mathrm{w}$ tym czasie, powstanie suwerennej Republiki Białoruś, nowa postimperialna rzeczywistość, wszystko to spowodowało w dziedzinie całej literatury białoruskiej istotne zmiany w obszarze tematyczno-problemowym i strukturalno-gatunkowym. Ten pierwszy związany był z możliwością podejmowania tematów trudnych, tematów, które w okresie obowiązywania estetyki socrealistycznej w zasadzie nie miały racji bytu, drugi z kolei - z wpływem literackich wzorców zachodnioeuropejskich, w szczególności dramaturgii absurdystycznej i postmodernistycznej, które z dużym opóźnieniem docierały na Białoruś i które stanowiły ważne źródło inspiracji drama-

${ }^{1}$ I. Babkou, O Odrodzeniu (II), [w:] idem, Królestwo Białoruś. Interpretacja ru(i)n, przeł. J. Maksymiuk, Wrocław 2008, s. 33. 
topisarzy średniego i młodego pokolenia, o czym świadczą między innymi następujące utwory: Teksty dramaturgiczne (Драматургічнья тэксть) Alesia Astaszonka, Książę Mamabuk (Прынц Мамабук) Alaksieja Dudarua, Labirynt (Лабірынт) і Ku-ku (Кy-кy) Mikoły Arachouskiego, Zmęczony diabeł (Стомлены д’ябал) і Powrót Głodomora (Вяртанне Галадара) Siarhieja Kawaloua, Epos, liryka i dramat, albo Życie ciepłego człowieka (Эпас, лірыка і драма як жыциё иёплага чалавека) Lawona Waszko, Głowa (Галава) і Babusie (Бабусечкі) Ihara Sidaruka, Vita brevis, albo Spodnie świętego Jerzego (Vita brevis, або Нагавіuыь святога Георгія) Maksima Klimkowicza i Mirasłaua Adamczyka czy Kolekcjoner (Калекцыьянер) Wolhi Hapiejewej ${ }^{2}$.

Ważnym zjawiskiem w obrębie sztuki dramaturgicznej był zwrot do kultury białoruskiej i ojczystej przeszłości. Poprzez dotarcie do źródeł rodzimej kultury i wskazanie na prezentowane przez nią wartości budowano poczucie tożsamości narodowej. Tak uporczywie stawiane przez białoruskich dramatopisarzy pytanie o przeszłość Białorusinów było w istocie pytaniem o własną tożsamość, która kształtowała się z takim trudem i w mało sprzyjających, zmiennych oraz niepewnych okolicznościach historycznych i politycznych. Stąd tak często podejmowano tematy historyczne, wykazywano wzmożone zainteresowanie gatunkiem dramatu i tragedii historycznej. Liczne białoruskie dramaty folklorystyczno-historyczne i historyczno-biograficzne, między innymi Dzwon to nie modlitwa (Звон - не малітва), Sprawa śledcza Waszczyły (Следчая справа Вашчылы), Igrce (Ігракі), Brat króla (Брат караля), Zagraj chłopcze mały (Зайграй, хлопча маль), Ościej-Olgierd (Ocuей-Альгерд) Iwana Czyhrynaua; Ruś Kijowska (Русь Kiеўская), Miecz Rogwołoda (Meu Рагвалода), To, со napisane, pozostaje (Напісанае застаещи,a), Strażnik wolności (Рыи,ар Свабоды), Ojсzyźniany prorok (Прарок для Айчыны), Wolność ukrzyżowапа (Воля на крыжы) Alesia Pietraszkiewicza; Rogneda i Włodzimierz (Рагнеда i Уладзімір), Кrzуż (Крыж), Książe Witold (Князь Bimay̆m), Czarna panna Nieświeża (Чорная панна Нясвіжа) Alaksieja Dudaraua; Legenda o Maszece (Легенда пра Машэку), Cztery historie Salomei (Чатыры гісторыі Cаламеi), Teatr Franciszki Radziwiłłowej (Францішка, або Навука кахання), Magiczne lustro pana Twardowskiego (Магічнае люстра пана Твардоускага) Siarhieja Kawaloua, odkrywały na nowo historyczne dzieje narodu białoruskiego i przybliżały sylwetki osób mających znaczący wpływ na rozwój kultury narodowej (Eufrozyna Połocka, Franciszek Skaryna, Franciszka Urszula Radziwiłłowa, Kastuś Kalinouski, Janka Kupała i in.).

Nie bez znaczenia dla rozwoju świadomości kulturowej Białorusinów było powstanie na przełomie lat osiemdziesiątych i dziewięćdziesiątych ubiegłego wieku trzech towarzystw literackich, które przez wiele lat kształtowały oblicze białoruskiego piśmiennictwa narodowego, a także stanowiły źródło nowych wzorców estetycznych i tematycznych. W 1987 roku powołano do życia stowarzyszenie literac-

${ }^{2}$ Więcej na ten temat zob. w: B. Siwek, Pomiędzy siła tradycji a doświadczeniem ponowoczesności, [w:] eadem, Wolność ukrzyżowana. Rzecz o białoruskim dramacie i teatrze, Lublin 2011, s. 85-115. 
kie „Tutejsi”, do którego należeli między innymi Adam Hlobus, Siarhiej Dubawiec, Siarhiej Kawalou, Andrej Fedarenka, Maksim Klimkowicz i Mirasłau Adamczyk. Warto podkreślić, że już poprzez samą nazwę białoruscy poeci i pisarze manifestowali swoją postawę artystyczną, wyraźnie ukierunkowaną na promowanie wartości narodowych, białoruskich. W manifeście stowarzyszenia czytamy:

Literatura - to Ojczyzna. Dla prawdziwego twórcy nie ma różnicy między ideałem narodowym a literackim. My traktujemy go jako najważniejsze literackie wyzwanie. Przybliżamy ten ideał — nieosiągnięty i nieosiągalny - akcjami obywatelskimi i aktami twórczymi³ ${ }^{3}$.

Jak konstatuje Jan Maksymiuk we wstępie do antologii nowej poezji białoruskiej Za niebokresem Europy, w nazwie stowarzyszenia zawarta jest też pewna doza samoironii:

„Tutejszymi” bowiem nazywali siebie i swój język wciąż niedookreśleni narodowo autochtoni na ziemiach pomiędzy Białymstokiem a Smoleńskiem, rzucani to $\mathrm{w}$ jedną, to $\mathrm{w}$ drugą stronę w politycznych przeciągach historii. Taka sytuacja została znakomicie spuentowana przez klasyka nowożytnej literatury białoruskiej Jankę Kupałę (1882-1942) w jego tragikomedii Tutejsi z roku 1922, skazanej przez bolszewicką krytykę na oficjalne nieistnienie, ale będącej już podstawą narodowej edukacji „Tutejszych” z roku $1987^{4}$.

W maju 1993 roku w Nowopołocku odbył się zjazd organizacyjny Towarzystwa Wolnych Literatów, organizacji grupującej około 30 osób młodego pokolenia literackiego. Inicjatorem i jednym z najbardziej aktywnych uczestników tego stowarzyszenia był poeta Aleś Arkusz. Podkreślić też należy niezwykłą aktywność wydawniczą Arkusza: wydanie szeregu tomików poetyckich z serii Poezja nowej generacji, które odkryły tak znaczące osobowości poetyckie, jak Jury Humaniuk (Grodno), Ihar Sidaruk (Kobryń) i Sławamir Adamowicz (Mińsk). Towarzystwo wydawało także swoje pismo literackie - nieregularnik „Kałośsie” („Калосьсе”). Od 1993 roku Towarzystwo Wolnych Literatów jest fundatorem nagrody literackiej Gliniany Weles, która co roku przyznawana jest autorowi najlepszej białoruskiej książki literackiej. Warto dodać, że Towarzystwo wydało dwa artykuły - Próba manifestu i Trzy lata na wolności - w których określiło swoje założenia programowe i postulaty ideowo-artystyczne ${ }^{5}$. O wiele bardziej radykalnym krokiem, dystansującym wcześniejsze konwencje, było powstanie grupy „Bum-Bam-Lit”. Grupa ta w pewnej mierze wzorowała się na ukraińskich bubabistach ${ }^{6}$, ale właściwie jedynie w odniesieniu do założeń czysto estetycznych. Ugrupowanie Bum-Bam-Lit w swej pierwotnej formie istniało je-

${ }^{3}$ Manifest Tutejszych, tłum. M. Wawrzeniuk, „Kartki” 1997, nr 1, s. 6.

${ }^{4}$ J. Maksymiuk, Posłowie, [w:] Za niebokresem Europy. Antologia nowej poezji białoruskiej 19871997, red. J. Maksymiuk, Białystok 1998, s. 112.

5 Zob. А. Аркуш et al., Заява сябраў Таварыства Вольных Літаратараў, „Літаратура і мастацтва" 1993, 14 мая, s. 3.

${ }^{6}$ Bubabistami powszechnie nazywano członków powstałej w 1987 roku z inicjatywy J. Andruchowycza i W. Neboraka ukraińskiej grupy literackiej Bu-Ba-Bu. Więcej na ten temat:

G. Gazda, Słownik europejskich kierunków i grup literackich XX wieku, Warszawa 2000, s. 60. 
dynie w latach 1995-1999, jednakże jego członkowie zajmują ważną pozycję na białoruskiej scenie literackiej. Są uczestnikami bądź twórcami niezwykle istotnych dla młodej literatury projektów wydawniczych (między innymi Drugi Front Sztuki czy Biblioteka Bum-Bam-Litu), ugrupowań literackich (np. Schmerzwerk) czy w końcu formacji kulturalnych (chociażby Teatr Psychicznej Nierównowagi) ${ }^{7}$. Liczni członkowie i aktywni uczestnicy wspomnianych stowarzyszeń literackich odegrali także znaczącą rolę w przestrzeni białoruskiego teatru narodowego i wyznaczyli kierunek rozwoju białoruskiego pisarstwa dramatycznego.

Nie ulega wątpliwości, że współczesny dramat i teatr białoruski rozwijają się w wyjątkowej sytuacji kulturowej, sytuacji polikulturowości, która — jak zauważa Vasil Novikau - nie tylko wynika z obiektywnego, geopolitycznego położenia Białorusi i wielonarodowości jej obywateli, ale też jest wypadkową obiektywnych procesów współdziałania międzykulturowego ${ }^{8}$. Białoruski badacz podkreśla, że historia świadomości społecznej Białorusinów sięga swoimi korzeniami wcześniejszych formacji socjokulturowych: Rusi Kijowskiej, Wielkiego Księstwa Litewskiego i Pierwszej Rzeczypospolitej, które ukształtowały unikatową wschodnioeuropejską przestrzeń socjokulturową, otwartą na różnego rodzaju wpływy światopoglądowe i zawierającą komponenty polietniczne i wielokulturowe ${ }^{9}$. Nie możemy o tym zapominać, analizując współczesne zjawiska zachodzące w obszarze białoruskiej kultury, w tym interesującego nas życia teatralnego i literackiego.

W zasadzie jeszcze do końca lat osiemdziesiątych XX wieku na Białorusi z 23 teatrów zawodowych zaledwie 3 były białoruskojęzyczne, a mianowicie: Teatr Akademicki im. Janka Kupały, Teatr Akademicki im. Jakuba Kołasa i Teatr Młodego Widza, a ich repertuar prawie niczym nie różnił się od repertuaru teatrów rosyjskich. Jak konstatuje dramaturg Siarhiej Kawalou:

Od Brześcia do Władywostoku były wystawiane te same sztuki autorów przeważnie moskiewskich oraz klasyka rosyjska i światowa. W zunifikowanym prowincjonalno-rosyjskim repertuarze dramat białoruski miał swój nieduży — ściśle określony tematycznie - przedział. Autorzy białoruscy w swoich utworach mogli chwalić bohaterskie czyny partyzantów II wojny światowej, pokazywać przemiany socjalistyczne na wsi, wyśmiewać drobnych biurokratów oraz walczyć z pijaństwem ${ }^{10}$.

Wystarczy tu przypomnieć teksty dramatyczne Kandrata Krapiwy, Mikoły Matukouskiego, Anatola Dzialendzika, Alesia Pietraszkiewicza czy Alesia Dudaraua. Nie można mówić w tym czasie jeszcze o gatunkowej różnorodności białoruskich

${ }^{7}$ Grupie tej poświęcona jest monografia: K. Bortnowska, Białoruski postmodernizm. Liryka pokolenia Bum-Bam-Litu, Warszawa 2009.

${ }^{8}$ V. Novikau, Narodowo-kulturowa tożsamość, wybór historyczny i dziedzictwo duchowofilozoficzne (Wspótczesna filozofia białoruska, red. H. Rarot), „Colloquia Communia” 2009, nr 1-2 (86-87), s. 11.

${ }^{9}$ Ibidem, s. 16-17.

10 S. Kawalou, Współczesny dramat białoruski, [w:] idem, Zmęczony diabeł. Dramaty, tłum. T. Giedz-Topolewska, B. Siwek, M. Sajewicz, Lublin 2004, s. 7. 
tekstów dramatycznych. Zdecydowanie dominowały w białoruskiej dramaturgii radzieckiej dramat wojenny i komedia satyryczna.

Na początku lat dziewięćdziesiątych XX wieku sytuacja ta uległa zdecydowanej zmianie. W niepodległej Białorusi na fali odrodzenia narodowego reżyserzy zaczęli zwracać większą uwagę na dramaturgię krajową. Przyczyniło się do tego również zerwanie kontaktów $\mathrm{z}$ autorami rosyjskimi w wyniku zniknięcia wspólnej przestrzeni teatralnej. Dużym powodzeniem cieszyły się realizacje klasycznych utworów dramaturgii białoruskiej: Tutejsi (Тутэйшья) і Rozrzucone gniazdo (Раскіданае гняздо) Janka Kupały, Idylla (Сялянка) Wincentego Dunina-Marcinkiewicza, Komedia (Камедыı) Kajetana Maraszeuskiego. Zwracano się także do zakazanej w czasach radzieckich spuścizny Franciszka Alachnowicza. Mikoła Truchan stworzył na podstawie jego tekstów wspaniałe spektakle - Czort i baba (Чopm i бaбa), Lęki życia (Страхі жыция) i Cienie (Цені) ${ }^{11}$. Mniej więcej w tym samym czasie zarówno białoruska scena teatralna, jak i literatura, w szczególności literatura dramatyczna, zaczynają przyswajać osiągnięcia zachodnioeuropejskiego teatru absurdu (Eugène’a Ionesco, Samuela Becketta, Sławomira Mrożka), który w zasadzie był im zupełnie nieznany (jeśli nie liczyć jedynego studyjnego spektaklu Czekając na Godota, wystawionego przez Rosyjski Dramatyczny Teatr im. Maksima Gorkiego w 1968 roku, co było sensacyjnym wyjątkiem). Sceny białoruskie zostały oddzielone od repertuaru zachodniego żelazną kurtyną. Wszechobecny był brak zaufania do awangardowej sztuki światowej i wykorzystywanych przez nią nowych form wyrazu, uznawanie ich za zjawisko szkodliwe dla narodowego dramatu i teatru. Praktycznie do lat osiemdziesiątych XX wieku osiągnięcia teatru absurdu nie istniały w teatrze i dramacie białoruskim. Dopiero w drugiej połowie lat osiemdziesiątych do estetyki teatru absurdu zwrócił się reżyser Ryd Talipow, który w swoim studiu teatralnym wystawił Striptiz Sławomira Mrożka oraz Kartotekę Różewicza. W latach dziewięćdziesiątych $\mathrm{XX}$ wieku dramaturgia absurdu zaczyna pojawiać się coraz częściej i to nie tylko $\mathrm{w}$ repertuarze teatrów studyjnych, ale też państwowych i - co należy podkreślić - oprócz dramatów zachodnioeuropejskich na białoruskiej scenie wystawiane były białoruskojęzyczne dramaty absurdu, choć ich recepcja nie należała do najlepszych. Przybliżaniu osiągnięć estetycznych absurdystów sprzyjał w znaczącym stopniu Republikański Teatr Dramatu Białoruskiego „Wolna Scena”, z którym związało swe losy wielu białoruskich dramatopisarzy średniego i młodego pokolenia. Pierwszym kierownikiem teatru był Walery Mazynski, znakomity reżyser, twórca najwybitniejszych realizacji teatralnych. Znaczenie tego teatru w kulturze Białorusi jest porównywalne do znaczenia eksperymentalnego teatru Antoine’a, który rozpoczął swoją działalność 30 marca 1887 roku, wprowadzającego na scenę najwybitniejsze dzieła dramaturgii europejskiej. Zaskakujące, że na Białorusi teatr tego rodzaju pojawił się tak późno. O jego roli Siarhiej Kawalou mówi:

${ }^{11}$ Inscenizacje te zostały zebrane w tomie: М. Трухан, Чаканні. Зборнік інсиэніровак па мастаикіх творах, Мінск 2001. 
Co do teatru „Wolnaja Scena” uważam, że powstanie tego projektu, biorąc pod uwagę wpływ na rozwój białoruskiej dramaturgii, było najważniejszym wydarzeniem w życiu teatralnym kraju lat dziewięćdziesiątych. Na scenie tego teatru ujrzały światło dzienne sztuki praktycznie wszystkich dramatopisarzy nowej generacji... ${ }^{12}$

Republikański Teatr Dramatu Białoruskiego rozpoczął swój pierwszy sezon teatralny w 1991 roku spektaklem Mikoły Arachouskiego Ku-ku, w reżyserii Andreja Huzija, a zatem dramatem aburdystycznym, co wywołało niemałą sensację w mińskim środowisku teatralnym. I choć w repertuarze tego teatru spotykać się będziemy częściej z spektaklami o bardziej ugruntowanej normie estetycznej, to w 1996 roku wystawiony zostaje na tej samej scenie dramat Dzmitryja Bojki Krwawa Mary (Крывавая Мэры) w reżyserii Alaksandra Harcujeua, a w 1997 - Mister Żartowniś (Mістэр Розыгрыш) Siarhieja Kandraszowa, a zatem spektakle realizujące zbliżony model estetyczny. Pojawiają się też dramaty Eugène’a Ionesco: Król umiera, Łysa śpiewaczka, Krzesła, dramaty Sławomira Mrożka: Emigranci, Dom na granicy, Szczęśliwe wydarzenie, Czarowna noc, Na pełnym morzu, Tango. Niektóre z wymienionych sztuk znajdą się z czasem w repertuarze także innych białoruskich teatrów, między innymi Państwowego Teatru Młodzieżowego, Mińskiego Obwodowego Teatru Dramatycznego m. Mołodeczno, Mohylewskiego Obwodowego Teatru Dramatycznego, Homelskiego Obwodowego Teatru Dramatycznego czy na małej scenie Państwowego Akademickiego Teatru Narodowego im. J. Kupały. Dopiero w 2000 roku na Białorusi wystawiono jedną z najciekawszych sztuk Ionesco, a mianowicie Szaleństwo we dwoje. Dramat ten został zrealizowany przez Państwowy Teatr Młodzieżowy w reżyserii W. Katawickiego.

Niestety, już po kilku latach działalności „Wolna Scena” przeżyła potężny kryzys, a ostatnim spektaklem wystawianym pod jej szyldem była komedia Alesia Dudaraua Książę Mamabuk, która notabene zaważyła na dalszym losie teatru, który dziś raczej hołduje dramaturgii rosyjskojęzycznej i zachodnioeuropejskiej niż białoruskojęzycznej.

W przedmowie do wydanej w 2011 roku antologii Nowa dramaturgia białoruska ${ }^{13}$ Andriej Moskwin pisze:

Nie jestem pewien, czy nowa białoruska dramaturgia jest w stanie zmienić oblicza współczesnego teatru białoruskiego. Raczej nie. Wielką przeszkodą jest panujący w kraju system zarządzania teatrami, obawa teatralnego kierownictwa przed radykalnymi zmianami oraz nieco skostniałe przyzwyczajenia białoruskiej publiczności ${ }^{14}$.

12 W poszukiwaniu tradycji. Z dramaturgiem Siarhiejem Kawalowem rozmawia Żana Łaszkiewicz, „Kresy” 2001, nr 1-2, s. 146.

${ }^{13} \mathrm{~W}$ antologii tej zamieszczono osiem utworów scenicznych napisanych w języku rosyjskim: Śniadanie na trawie Jeleny Popowej, Przyszedłem Nikołaja Chalezina, Tra-ta-ta Anatola Szurpina, Mężczyzna - kobieta - pistolet Konstantina Ścieszyka, Serpentyna Pawła Priażko, Pajęczyna bełkotliwości, pajęczyna kłamstwa..., Cień i Niemy poeta Grigorija Cisieckiego (wszystkie w przekładzie Karoliny Niewiadomskiej). Zob. A. Moskwin, Nowa dramaturgia białoruska, Warszawa 2011.

${ }^{14}$ Ibidem, s. 15. 
I wiele jest racji w tym stwierdzeniu. Obecnie na Białorusi działa dwadzieścia osiem teatrów państwowych, które w większości są uzależnione od budżetu Ministerstwa Kultury (repertuar teatrów w dużej mierze zależy od korzyści ekonomicznych, a zatem dyrektorzy placówek teatralnych znajdują się w swoistej pułapce polityczno-społecznej). Dominuje w nich repertuar klasyczny oraz dramaturgia okresu radzieckiego.

Przegląd aktualnego repertuaru białoruskich teatrów w sposób oczywisty ukazuje ich preferencje estetyczne i tematyczne, a także nie pozostawia złudzeń co do rangi współczesnej dramaturgii białoruskojęzycznej na białoruskiej scenie. W ofercie repertuarowej Akademickiego Teatru Narodowego im. J. Kupały w listopadzie 2014 roku znalazły się między innymi takie sztuki: Paulinka (Паўлінка) Janka Kupały, Porwanie Eитору (Выкраданне Еўропь) Franciszki Urszuli Radziwiłłowej, Czarna panna Nieświeża (Чорная панна Нясвіжа) Alaksieja Dudaraua, Wesele (Свадьба) Antoniego Czechowa, Noc wigilijna (Ночь перед Рождеством) Mikołaja Gogola, Don Juan Moliera, Pan Tadeusz Adama Mickiewicza, Panna Julia Augusta Strindberga, z najnowszej dramaturgii — rosyjskojęzyczny dramat Tata (Tama) Dmitryja Bogosławskiego ${ }^{15}$; natomiast w Republikańskim Teatrze Dramatu Białoruskiego: Intymny dziennik (Iнтымны дзённік) Siarhieja Kawaloua, Trzy Giselle (Tры Жььзелі) Andreja Kurejczyka, Kupała. Kręi raju (Купала кругі раю) Swiatłany Nawumienki, A jeśli nie ma jutra (А если завтра нет) Dmitryja Bogosławskiego, Mister Żartowniś (Miстэр Pозыгрыш) Siarhieja Kandraszoua, Stolica Around (Сталіца Эраўнд) Siarhieja Hirhiela, Rozrzucone gniazdo (Раскіданае гняздо) Janki Kupały, Biały anioł z czarnymi skrzydłami (Бельь анёл з чорнымі крыламі) Dyjany Bałyka ${ }^{16}$ - zatem, podobnie jak w teatrze Kupałowców, klasyka krzyżuje się z rosyjskojęzyczną dramaturgią współczesną, natomiast sporadycznie pojawiają się dramaty współczesnych twórców białoruskojęzycznych.

Można by się zastanowić, co jest przyczyną takiego stanu rzeczy i co sprawia, że dramaturgia rosyjskojęzyczna zdecydowanie dominuje w teatrach białoruskich nad białoruskojęzyczną. Czym spowodowany jest fakt, że to dramaturgia rosyjskojęzyczna właśnie przyciąga swoją uwagą teatry zagraniczne - i rosyjskie, i polskie. Skąd takie powodzenie Dmitrija Bogosławskiego, którego sztuki odnajdujemy na afiszach dwóch najważniejszych teatrów białoruskich, a także w teatrach polskich (między innymi w Teatrze Współczesnym w Warszawie, w reżyserii Wojciecha Urbańskiego)? ${ }^{17}$. Jak to się dzieje, że bardziej niż białoruskie teatry narodowe, cieszą

15 Repertuar Narodowego Akademickiego Teatru im. J. Kupały, listopad 2014, http://kupalauski. by/whatson/playbill/ [dostęp: 11.11.2014].

${ }^{16}$ Repertuar Republikańskiego Teatru Dramatu Białoruskiego, listopad 2014, http://rtbd.by/flat/ [dostęp: 11.11.2014].

17 O D. Bogosławskim reżyser Wojciech Urbański mówi: „Bogosławski pisze po rosyjsku, ponieważ młody dramatopisarz piszący po białorusku nie ma dużych szans zaistnieć w swoim kraju. Trzeba być bardzo uznanym autorem, żeby zostać wystawionym w teatrze w Mińsku. Większość dramatopisarzy białoruskich pisze po rosyjsku i ma swoje prapremiery w Rosji i za granicą". Zob. Opisywać rzeczywistość, jaka jest. Rozmowa Joanny Biernackiej i Wojciecha Urbańskiego, „Dialog” 2014, nr 1, s. 209. 
się międzynarodową sławą teatry niezależne, eksperymentalne: Wolny Teatr z Mińska oraz Korniag-Theatre Jewgienija Korniaga? ${ }^{18}$

Teatr Wolny, założony w 2005 roku w Mińsku przez Mikałaja Chalezina i Natallę Koladę, jest bez wątpienia najbardziej znanym teatrem poza granicami Białorusi. Działa w warunkach konspiracyjnych. Spektakle odbywają się zazwyczaj potajemnie w najróżniejszych lokalizacjach, a niemal każde jego przedstawienie w Mińsku jest przerywane przez funkcjonariuszy milicji ${ }^{19}$. Jego sztuki należą do nurtu sztuk politycznie zaangażowanych, podejmujących istotne problemy współczesnej rzeczywistości białoruskiej. Jeden z najbardziej znanych spektakli tej grupy - Być jak Harold Pinter (Быть Гарольдом Пинтером) - był z powodzeniem wystawiany w Polsce, Rosji, Anglii, Stanach Zjednoczonych. Sztuka ta łączy wypowiedzi białoruskich więźniów politycznych demaskujących nadużycia władzy z fragmentami zaczerpniętymi z twórczości brytyjskiego laureata Nagrody Nobla Harolda Pintera, w szczególności z jego mowy noblowskiej. Pinter, a za nim artyści Wolnego Teatru, poszukują odpowiedzi na kluczowe w życiu każdego twórcy pytania: W jaki sposób powstaje sztuka teatralna? Jaka jest różnica pomiędzy prawdą w życiu i prawdą w sztuce? Czy artysta powinien być zaangażowany w politykę?

Z kolei lider Korniag-Theatre Jewgienij Korniag jest dziś nazywany najważniejszą postacią „młodego” życia teatralnego na Białorusi. Tworzy przedstawienia bez słów, utrzymane w konwencji teatru plastycznego, inspirowane estetyką teatru tańca Piny Bausch. Spektakle te (np. Spektakl nr 7) są przepełnione niezgodą i sprzeciwem wobec białoruskich realiów życia i sposobu prowadzenia polityki ${ }^{20}$.

Ważną inicjatywą ostatnich lat było wznowienie działalności Centrum Białoruskiej Dramaturgii i Reżyserii, utworzonego w 2003 roku przy Białoruskiej Akademii Sztuki, w ramach którego odbywały się czytania najnowszych utworów białoruskiej i zachodniej dramaturgii, dyskusje, spotkania $\mathrm{z}$ autorami tekstów, warsztaty online $\mathrm{z}$ udziałem młodych autorów i reżyserów. Wszystko to jednak za mało, żeby mówić o prawdziwym przełomie w białoruskim teatrze współczesnym. Często można usłyszeć opinie, że proponowany przez białoruski teatr wzorzec artystyczny nie odpowiada trendom światowym, za mało jest w nim bowiem miejsca na eksperyment, nowatorstwo i innowacyjność ${ }^{21}$. Nie bez znaczenia jest też fakt, iż na Białorusi brak pisma, które zajmowałoby się publikacją najnowszych sztuk białoruskich dramatopisarzy, czy też takiego, które poświęcone byłoby w całości zjawisku teatru. Przypomnijmy, iż w latach dziewięćdziesiątych XX wieku wydawane były czaso-

${ }^{18}$ Jewgienij Korniah jest reżyserem i instruktorem teatralnym. W 2005 roku ukończył Białoruską Państwową Akademię Sztuki, a w 2011 roku studia podyplomowe w Szkole-Studiu Niemirowicza-Danczenki działającej przy Moskiewskim Akademickim Teatrze Artystycznym im. Antona Czechowa.

${ }^{19}$ W lutym bieżącego roku Teatr Wolny został uhonorowany w Warszawie nagrodą Karty '97 im. Wiktara Iwaszkiewicza „za odwagę w twórczości”.

${ }^{20}$ Więcej na ten temat zob. http://korniag-theatre.com/plays.html [dostęp: 9.11.2014].

${ }^{21}$ D. Przastek, Białoruskie impresje, http://www.teatr-pismo.pl/przeglad/209/bialoruskie_impresje/ [dostęp: 10.11.2014]. 
pisma „Teatralna Białoruś” („Тэатральная Беларусь”) i „Białoruska Dramaturgia” („Беларуская драматургія”).

Anna Kuligowska-Korzeniewska w eseju Niemy poeta, czyli o dramacie i teatrze białoruskim, w którym dzieli się swoimi wrażeniami z podróży na Białoruś w związku z udziałem w Międzynarodowym Kongresie Slawistów, stawia dość smutną diagnozę współczesnemu teatrowi białoruskiemu:

Mogę więc pytać, jak to czyniłam w końcu 2013 roku w Mińsku: gdzie jesteś, białoruski teatrze?! Miałam przecież nadzieję, że w Narodowym Teatrze Akademickim im. J. Kupały czy w Narodowym Akademickim Teatrze im. J. Kołasa usłyszę język białoruski! Tymczasem w tym wielkim mieście, stolicy Białorusi, wszystkie białoruskie sceny były nieczynne. Z powodu kanikuły, jak mi wyjaśniono. $\mathrm{Ta}$ „kanikuła” nie przeszkadzała jednak kilku teatrom rosyjskim grać przy pełnej widowni, czego sama doświadczyłam... Wciąż więc „niemy poeta” ze sztuki Cisieckiego nie przemówił22.

Nawiązując do tych słów, należy podkreślić, że zdecydowanie częściej jednak niż dramaturdzy białoruskojęzyczni przemawiają na białoruskich i światowych scenach autorzy rosyjskojęzyczni - Paweł Priażko, Mikałaj Chalezin, Jelena Popowa, Andrej Kurejczyk, Siarhiej Hirhiel, Anatol Szurpin, Konstanty Ścieszyk, Andrej Karelin, Mikałaj Rudkouski, a zatem najbliższy prawdy na temat kulturowego oblicza Białorusi wydaje się Ihar Babkou, kiedy stwierdza, że rzeczywistość kulturalna Białorusi jest wojną kultur z jej wszystkimi następstwami empirycznymi i metafizycznymi $^{23}$.

${ }^{22}$ A. Kuligowska-Korzeniewska, Niemy poeta, czyli o dramacie i teatrze białoruskim, „Dialog” 2014, nr 1, s. 217.

${ }^{23}$ I. Babkou, op. cit., s. 113. 